\title{
Modeling reaction time and accidents rate of drivers
}

\author{
Hayder M. A. Alkhafaji ${ }^{1, *}$, and Saad Issa Sarsam ${ }^{2}$ \\ ${ }^{1}$ Department of civil engineering, university of Baghdad,Baghdad,Iraq, hyder_alkhafaji@yahoo.com \\ ${ }^{2}$ Department of civil engineering, university of Baghdad, Baghdad, Iraq, saadisasarsam@coeng.uobaghdad.edu.iq \\ *Corresponding author: Hayder M. A. Alkhafaji,email: hyder_alkhafaji@yahoo.com \\ Published online: 31 August 2019
}

Abstract-The huge number of accidents makes the study of accidents causation one of the priorities in the design of roads, location of traffic signs, specifying the permitted ages for driving, improving license procedure and to provide local data to predicate the behavior. The characteristics of drivers affect results in roads. Drivers' data, vision test and reaction time of the drivers taken, head cover and spectacle considered in the drivers' abilities and accidents background involvements in the questionnaire form. Drivers' reaction time and drivers' accidents rate (accidents +1 /experience) through the years of driving experience are modeled. The results revealed the negative impact of head cover and/or spectacle on vision abilities, while it didn't show obvious effect on accidents rate The best reaction time is 0.5708 ( $\mathrm{sec}$ ) for age group (29-39) years, while the worst reaction time is 0.6974 for age $(>=51)$ years. The maximum accident rate is 0.482 for age group (18-28) and decreases with age increase to a minimum accidents rate of 0.0808 for age group $>=51$.

Keywords- Reaction time, Accidents rate, drivers' characteristics, head cover.

\section{Introduction}

One of the most important problems that designers in the field of highways, roads, streets and other transportation means face are drivers characteristics, the drivers differs from each other in abilities, their abilities divided into the vision, hearing, evaluating and reacting to situations in roads, another factor of the difference in drivers characteristics variations and attributed to drugs, alcoholic drinks and the state of the drivers of being tired, sleepy or exhausted [2], the study focus on the problem that is taken under consideration and gave it the priority in research, the increase in number of accidents in Iraq followed the increase in number of various types of vehicles after 2003 to reach the 5.8 million vehicles in Baghdad as the statistics that are collected from general traffic directorate in Baghdad. Vision test and drivers' characteristics at Mosul city evaluated. The results show that vision test must be used in driving licensure. Head cover and eye class, worsen the vision of drivers in all meridian cases [6]. the safety effects of Swedish drivers teaching at 16 years old evaluated, to increase the period of learning and to gain more skills, the results shows decrease in the odds of dangers, while it did not in the absent of practicing before driving. The advantages of learning programs for small age drivers did not appear immediately, the research extract proved the need for continuous enhancing system for such training programs that are useful in safety issues [3]. The drivers' characteristics in commercial Baghdad district estimated. The clear and peripheral vision angles assessed. Tradition and spectacle were considered. The Perceptionreaction time for various drivers was within limits. The wear of spectacle and head cover worsen field of vision to driver eye in horizontal meridian by 20 percent for peripheral vision and 42 percent for clear vision [7]. The reaction time of drivers were examined by $[7,8]$, the results revealed that the second higher age group is of the optimum speed in response time, the reaction time values are 0.775 second for first research and 0.77 and 0.8 for males in urban and suburban, area and recorded equal value of 0.81 seconds for females in both mentioned areas for second research. The behavior and characteristics of drivers in Mosul and its relation with accidents participation demonstrated, and discovered that drivers of old age $>50$ less participated in accidents. The reaction time of different age groups were tested and finds that reaction time of over than 50 years old is the maximum value, the second maximum group is $41-50$ years, the third is $18-30$, the best group is $31-40$ years old. the minimum value of reaction time occurred with the increase in age for the second age group, and the reason of such enhancement in response time due to the increase in experience and 
confidence of drivers, the maximum value of drivers' reaction activity increases with the increase in age and that's mean elderly drivers suffering from slow reactions (high reaction value), due to the reduction in their abilities [6]. A studies recognized young drivers of highest involvements of accidents percents up to 30 years old and old drivers of the lowest percent in participating in accidents over 50 years, because they are more conservative in knight driving.

\section{Methodology}

The drivers' characteristics were studied, their performance while breaking, when sudden incidents occurred in the road, and the perception reaction time of a driver for various age groups will be evaluated. Questionnaire form prepared to each driver, the form containing age of driver, experience of driving, average hours of driving daily, education level, traffic education, road accident participation (the whole life), tradition and spectacle wearing Accidents information was taken From the general directorate of traffic; the information of real traffic accidents was compared and related to the sample data of drivers that is tested by the previous mentioned methods. Two mathematical models were found that explain the data of the drivers.

\subsection{Site of experimental work}

The sites of experimental field test are AL-Alawy garage (north \& south garages), Bayaa garage, Nahda garage, Dura garage, the reasons of choosing garages for experimental tests are the presence of many drivers that are not busy because they wait their turn for transporting passengers to the required places in all the cities in Iraq, all the sample drivers from males, the number of drivers that are tested is 1052 driver, from January to June 2018. Figure 1 contain of pictures of two important garages in Baghdad AL-Alawy \& AL-Nahda garage that are considered of the two big garages in Iraq.

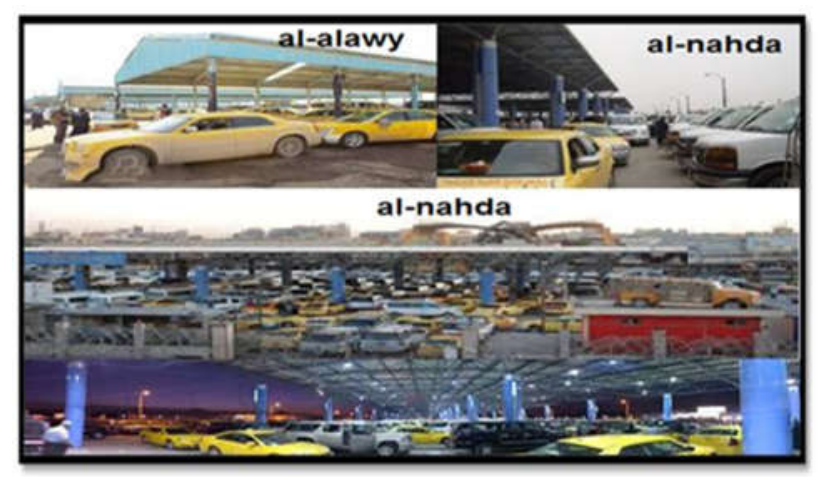

Figure 1: the various vehicles in two garages in Baghdad CBD
Figure 2 shows the location of the 4 important places to test drivers in Baghdad CBD (Dura, Baya, Alawy and Nahda).

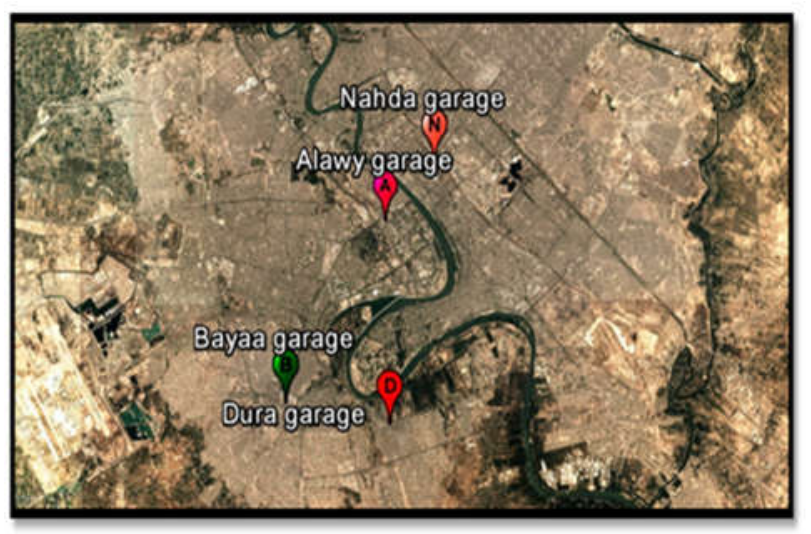

Figure 2: the 4 important places for garages in Baghdad CBD (google earth pic.)

\subsection{Measurement method and tools}

To measure the angles of vision (clear and peripheral) for horizontal and vertical meridians, half circle of wood manufactured by the carpenter and all the dimensions of the semi circle chosen to a value that it would be easier for the tester to carry it to the site. It is divided to equal degrees, $70 \mathrm{~cm}$ diameter, the tester put the half circle in front of the driver, in his neck, the driver asked to look forward, and for Clear angle of vision $(\mathrm{CH})$ a test cards having different shapes (circle, triangle, rectangle), with different colors (red, green, blue, black) used for that purpose. The test card moved from the centre of the half circle slowly to the sides of the circle and making sure that the driver's eyes forwards and the tester hands under the half circle that is not observed by the drivers eye, and asking the driver for clear vision, some colors except black changed to black while testing the drivers, after that, the shape becomes unclear. If that happened we stepped back till the shape becomes clear and that is called the angle of clear vision, this process accomplished twice from centre to the right, and from centre to the left, the summation of both degrees represent the total angle of clear vision for both eyes of the driver. The same procedure for the angle of clear vision $(\mathrm{CV})$ but reversing the half circle beside the driver head, and making sure of the centered location, and fixing it vertically by drivers' hands, by moving the test card from the centre of the half circle to up and down, the summation of two readings represent the $(\mathrm{CH})$ above and down the line of sight. The use of different shapes and colors makes the reading for same driver having errors because of the difference in colors perceptions from driver to driver, so the tester uses the red color to the circle only to unify the reading for all drivers after examining the data results and making corrections to the way of objects moving (colored shape) and speed of the process [9]. Figure 3 shows the test cards used and pens used in the angle's measurements. 


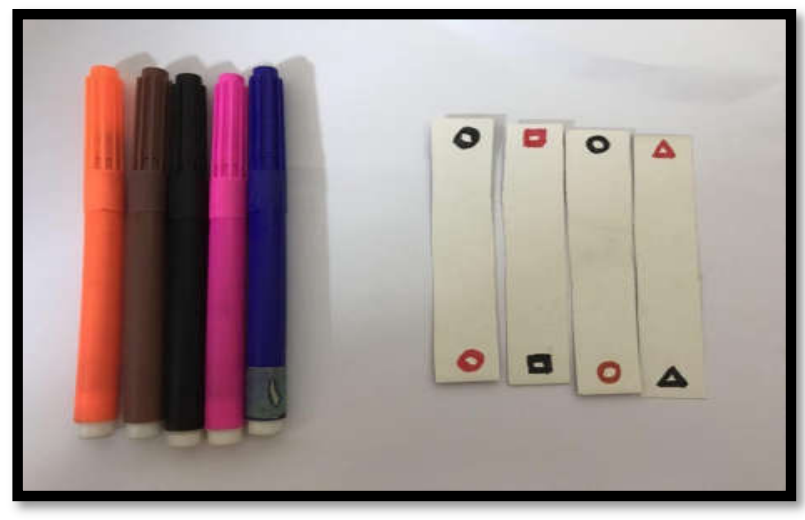

Figure 3: cards test for clear angles\& pens for peripheral angles

Figure 4 and Figure 5 illustrate the way to measure the angles by semicircle.

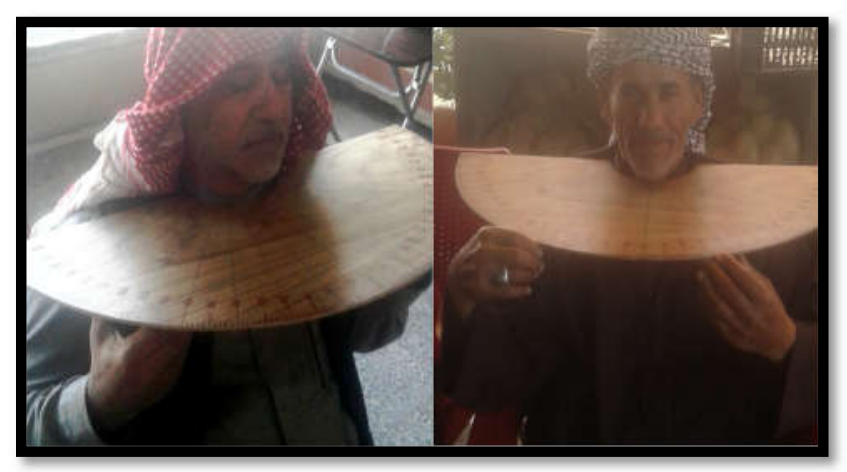

Figure 4: drivers with half circle from wood to $\mathrm{PH} \& \mathrm{CH}$ measure

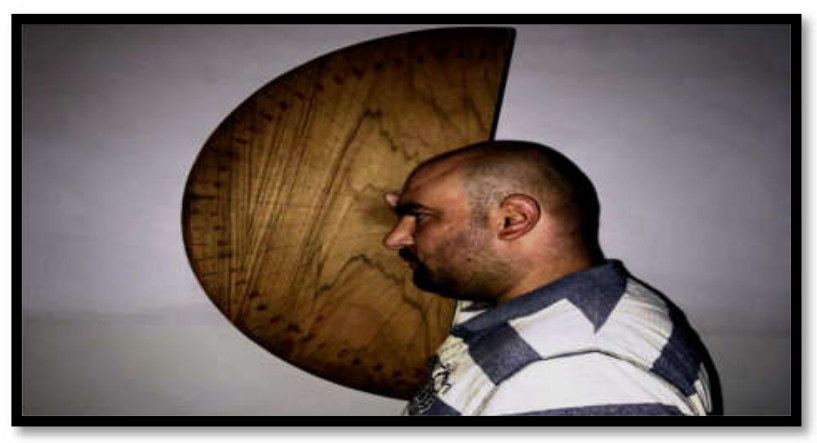

Figure 5: PVand CV shape measurements

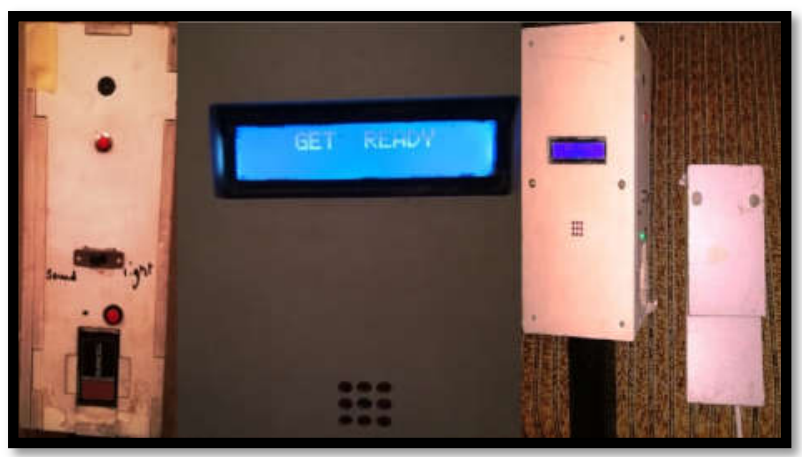

Figure 6: the battery, screen, and pedal for the reaction time device

Figure 7 shows the way to test driver in his state of tradition and/or spectacle wearing. The driver sits on a chair and distracted by a conversation and suddenly the red lamp lighted suddenly and that's mean a sudden incidents occurred while driving needed a response from driver to break, and this is a simulation for real driving situations.

\subsection{Range of data ages collected}

ages from 18-72 years old divided into 4 groups.

\subsection{Tradition cases and types}

The cases of tradition and/or spectacle wearing are 4 cases and the head cover differs in its folds as shown by Figure 7 and Figure 8.

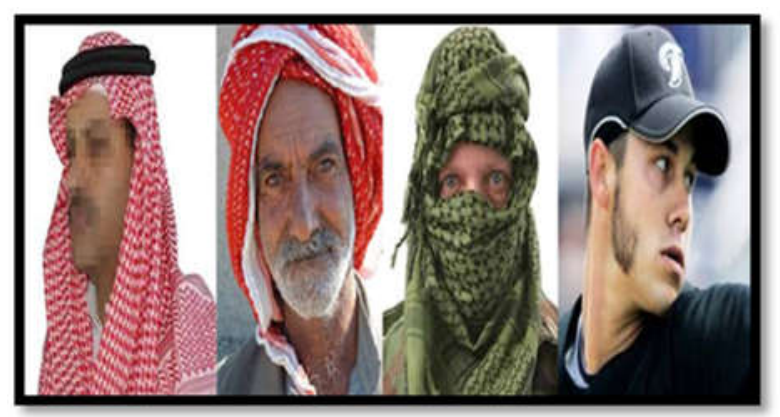

Figure 7: The Folds of head cover and types. 


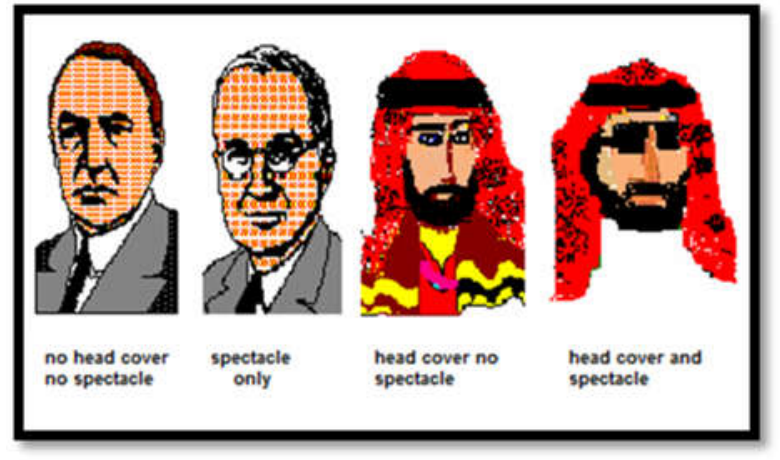

Figure 8: four cases of tested drivers [6]

\section{Results and discussion}

\subsection{Reaction time and accidents rate models}

The modeling is a method used to predict the relation of dependent variables with independent variable, in the form of equations that is valid statistically, the steps for modeling started with knowing the effective variables and the shape of relation, and the strength of the models. The final equation that is modeled includes (reaction time and accidents rate) as dependent variables related to drivers characteristics. Many methods can be used to find this relation and the coefficient of variation to the models. The stepwise regression analysis is used for the calculation of the most appropriate models that describe the linear equations.

\subsection{Variables used in equations}

The following variables used to predict the models

$\mathrm{RT}=$ response time of drivers to sudden incidents in road based on simulated device for that purpose (seconds).

Rate $=$ rate of accidents (number of accidents +1 ) per years of experience for driver [1].

Age $=$ age of driver (years).

Dhours=driving hours per day (hours/day)

Dexperience $=$ years of experience for drivers (years)
$\mathrm{CH}=$ horizontal angle of clear vision (degree)

$\mathrm{CV}=$ vertical angle of clear vision (degree)

$\mathrm{PH}=$ horizontal angle of peripheral vision (degree)

$\mathrm{PV}=$ vertical angle of peripheral vision (degree)

Spectacle $\&$ head cover wearing two variables denoted as ( $2=$ yes, $1=$ no)

\subsection{Sample size calculations}

Sample size calculation used from equation (1), [4], knowing that level of confidence is 0.95

$$
n=p(1-p)\left[\frac{\mathrm{Z} \alpha / 2}{E}\right]^{2}
$$

$\mathrm{n}=$ sample size

$\mathrm{p}=$ proportion of sample size

$\mathrm{z} \propto / 2=\mathrm{z}$ score $=1.96$

$\mathrm{E}=$ significant level (0.05)

Maximum $\mathrm{n}$ occurred when the proportion $\mathrm{p}=0.5$, so 384 is the corresponding value as in Table 1 .

Table 1: sample size determination

\begin{tabular}{|c|c|c|c|}
\hline & Std.dev. & $\mathbf{N}$ & $\begin{array}{c}\text { Max. } \\
\text { sample } \\
\text { size req. }\end{array}$ \\
\hline Reaction time(sec.) & 0.125 & 804 & 384 \\
\hline $\begin{array}{c}\text { Accident } \\
\text { rate(accidents/year) }\end{array}$ & 0.073 & 675 & 384 \\
\hline
\end{tabular}

\subsection{Outlier's detections}

the experimental work includes collected data, the distribution of data contains of group concentrated within limited margin calculated from the frequency of data, but sometimes due to mistakes or other abnormal condition, a data set considered as extreme or outliers and by checking those extreme values using Chauvinist's criterion and absolute tabulated of sample size value [5] as in Table 2 the accuracy checked. The maximum and minimum values substituted in the equations forms and all the values are less than tabulated values, so there are no outliers.

Table 1: chauvinist's test

\begin{tabular}{|c|c|c|c|c|c|c|c|c|}
\hline & $\mathbf{N}$ & $\begin{array}{c}\min \\
\text { value }\end{array}$ & Mean & $\begin{array}{c}\max \\
\text { Value }\end{array}$ & $\begin{array}{c}\text { Std. } \\
\mathbf{d e v} .\end{array}$ & $\left|\frac{\text { xmin-mean }}{s}\right|$ & $\left|\frac{\text { xmax-mean }}{s}\right|$ & $\begin{array}{c}\mid \frac{x m-\text { mean }}{\boldsymbol{s}} \\
\text { Tabulated }\end{array}$ \\
\hline Reaction time & 804 & 0.212 & 0.522 & 0.877 & 0.125 & 2.48 & 2.84 & 3.407 \\
\hline Accident rate & 675 & 0.02 & 0.0985 & 0.222 & 0.0485 & 1.619 & 2.546 & 3.358 \\
\hline
\end{tabular}




\section{5 normality test}

The advantage of the Kolmogorov-Smirnov test is to know the normality and to test the null hypothesis, and if the null hypothesis is accepted, then the data is normally distributed. $\mathrm{Z}$ value of The Kolmogorov-Smirnov is determined from largest value of subtraction the observed from theoretical value of a function cumulatively distributed (neglecting positive and negative sign), the test shows the distribution type if it is normal or other than normal type or the observation is not coming from distribution type. Table. 3 shows results of normality test based on SPSS software analyses version 23. It seems there is a problem in normality depending on significant that is less than 0.05 . The 4 tests in Kolmogorov-Smirnov test for the types of distribution revealed that the data of reaction time and accidents rate, do not represent any of the four distributions in the test because of the p-value is less than 0.05 in all the cases.

Table 3: one -sample K-S test for drivers' reaction time and rate of accidents.

\begin{tabular}{|c|c|c|c|}
\hline \multirow{2}{*}{\multicolumn{2}{|c|}{ N (70\% of sample) }} & $\begin{array}{c}\text { Reaction } \\
\text { time }\end{array}$ & $\begin{array}{l}\text { Accidents } \\
\text { rate }\end{array}$ \\
\hline & & 564 & 470 \\
\hline \multicolumn{2}{|c|}{$\begin{array}{l}\text { Normal parameters mean } \\
\text { Standard deviation }\end{array}$} & $\begin{array}{l}0.521 \\
0.125\end{array}$ & $\begin{array}{l}0.0967 \\
0.0483\end{array}$ \\
\hline \multirow{3}{*}{$\begin{array}{l}\text { Most extreme } \\
\text { differences }\end{array}$} & absolute & 0.054 & 0.101 \\
\hline & Positive & 0.054 & 0.101 \\
\hline & Negative & -0.044 & -0.056 \\
\hline \multicolumn{2}{|c|}{ Kolmogorov-Simirnov Z } & 4.740 & 4.640 \\
\hline \multicolumn{2}{|c|}{ Asymp. Sig. (2-tailed) } & 0.000 & 0.000 \\
\hline
\end{tabular}

\subsection{Multicollinearity}

to identify the multicollinearity among the independent variables by correlating between them, the predictors that are highly correlated affect the evaluation of model, and must be removed or entered step by step depending on significance for each variable and the final strength of predicted equation and the enhancement in the coefficient of determination( $\mathrm{R}^{\wedge} 2$ ). Table 4 and Table 5 shows the correlation between each independent variable with other independents alone for all the variables used in modeling (bivariate correlation matrix of accidents rate and RT models). The applications used to find such correlations is (IBM SPSS Statistics v23 x64), the (+ve) sign is an indication of positive relationship (the higher the variable the higher the other variable, while (-ve) sign is an indication of negative relationship (the higher the variable the smaller the other variable). In spite of high collinearity for age and Dexperience (+ve. linear relation) we include it in both models because of its significance on reaction time prediction with age and it is not very high to cause a problem in the prediction. the accident rate model as dependent variable calculated by dividing the total accidents +1 by Dexperience, noting that we add 1 to number of accidents to recognize between the risks of the drivers with high experience and low experience with no accidents [1]. The $\mathrm{CV}$ and $\mathrm{CH}$ highly correlated in accidents rate matrix and because they are highly non significant they can be excluded from accidents rate, while they are significant in reaction time model.

Table 2: Correlations matrix of accidents rate variables

\begin{tabular}{|c|c|c|c|c|c|c|c|c|}
\hline $\begin{array}{c}\text { PEARSON } \\
\text { CORRELATION }\end{array}$ & AGE & DEXPERIENCE & DHOURS & CH & CV & PH & PV & RT \\
\hline AGE & 1 & .836 & .211 & $-.052-$ & $-.107-$ & $-.312-$ & $-.228-$ & .277 \\
\hline DEXPERIENCE & .836 & 1 & .258 & $-.059-$ & $-.100-$ & $-.276-$ & $-.199-$ & .203 \\
\hline DHOURS & .211 & .258 & 1 & .004 & $-.030-$ & $-.058-$ & $-.108-$ & .058 \\
\hline CH & $-.052-$ & $-.059-$ & .004 & 1 & .894 & .165 & .267 & $-.046-$ \\
\hline CV & $-.107-$ & $-.100-$ & $-.030-$ & .894 & 1 & .184 & .332 & $-.092-$ \\
\hline PH & $-.312-$ & $-.276-$ & $-.058-$ & .165 & .184 & 1 & .362 & $-.237-$ \\
\hline PV & $-.228-$ & $-.199-$ & $-.108-$ & .267 & .332 & .362 & 1 & $-.223-$ \\
\hline RT & .277 & .203 & .058 & $-.046-$ & $-.092-$ & $-.237-$ & $-.223-$ & 1 \\
\hline
\end{tabular}


Table 5: Correlation matrix of reaction time variables

\begin{tabular}{|c|c|c|c|c|c|c|c|c|c|}
\hline $\begin{array}{c}\text { PEARSON } \\
\text { CORRELATION }\end{array}$ & AGE & DEXPER. & DHOURS & CH & CV & PH & PV & SPEC. & TRAD. \\
\hline AGE & 1 & .864 & .301 & -.024 & -.075 & -.283 & -.256 & .067 & .212 \\
\hline DEXPER. & .864 & 1 & .357 & .010 & -.032 & -.274 & -.230 & .022 & .172 \\
\hline DHOURS & .301 & .357 & 1 & .031 & .032 & -.123 & -.185 & .028 & .077 \\
\hline CH & -.024 & .010 & .031 & 1 & .877 & .244 & .224 & -.200 & -.171 \\
\hline CV & -.075 & -.032 & .032 & .877 & 1 & .268 & .286 & -.231 & -.193 \\
\hline PH & -.283 & -.274 & -.123 & .244 & .268 & 1 & .401 & -.193 & -.216 \\
\hline PV & -.256 & -.230 & -.185 & .224 & .286 & .401 & 1 & -.178 & -.238 \\
\hline SPECTACLE & .067 & .022 & .028 & -.200 & -.231 & -.193 & -.178 & 1 & .240 \\
\hline TRADITION & .212 & .172 & .077 & -.171 & -.193 & -.216 & -.238 & .240 & 1 \\
\hline
\end{tabular}

\subsection{Stepwise Regression models}

To find the coefficients of the predictors, we can use one of the methods in finding the value of parameters; the table below shows the summery of calculations by using stepwise with default $\mathrm{F}$ to enter equal to 3.84 and depending on probability criteria or $F$ out value the convergence decide the final model with its variables, Table 6 and Table 7 shows the summary of accidents rate and RT models calculations, while Table 8 and Table 9 shows the coefficients predicted for accidents rate and reaction time models.
Table 6: Model Summary of accidents rate

\begin{tabular}{|c|c|c|c|c|}
\hline Model & $\mathrm{R}$ & $\mathrm{R}$ Square & $\begin{array}{c}\text { Adjusted R } \\
\text { Square }\end{array}$ & $\begin{array}{c}\text { Std. Error of } \\
\text { the Estimate }\end{array}$ \\
\hline 1 & .945 & 0.893 & 0.889 & 0.038 \\
\hline
\end{tabular}

Table 7: Model Summary of reaction time

\begin{tabular}{|c|c|c|c|c|}
\hline model & R & R Square & $\begin{array}{c}\text { Adjusted R } \\
\text { Square }\end{array}$ & $\begin{array}{c}\text { Std. Error of } \\
\text { the Estimate }\end{array}$ \\
\hline 1 & 0.972 & 0.945 & 0.944 & 0.1261997 \\
\hline
\end{tabular}

Table 8: the ceofficients of accident rate

\begin{tabular}{|c|c|c|c|c|c|c|c|}
\hline \multirow[t]{2}{*}{ Model } & \multicolumn{2}{|c|}{ Unstandardized Coefficients } & \multirow{2}{*}{$\begin{array}{c}\begin{array}{c}\text { Standardized } \\
\text { Coefficients }\end{array} \\
\text { Beta }\end{array}$} & \multirow[t]{2}{*}{$\mathrm{t}$} & \multirow[t]{2}{*}{ Sig. } & \multicolumn{2}{|c|}{$\begin{array}{c}95.0 \% \text { Confidence Interval for } \\
\text { B }\end{array}$} \\
\hline & B & Std. Error & & & & Lower Bound & Upper Bound \\
\hline AGE & .001 & .000 & .473 & 3.914 & .000 & .001 & .002 \\
\hline DEXPERIENCE & $-.003-$ & .000 & $-.740-$ & $-9.615-$ & .000 & $-.004-$ & $-.002-$ \\
\hline DHOURS & .001 & .001 & .036 & .862 & .389 & $-.001-$ & .002 \\
\hline $\mathrm{CH}$ & .000 & .000 & .055 & .500 & .617 & .000 & .001 \\
\hline $\mathrm{CV}$ & $2.011 \mathrm{E}-5$ & .000 & .005 & .048 & .962 & $-.001-$ & .001 \\
\hline $\mathrm{PH}$ & .001 & .000 & .739 & 6.587 & .000 & .000 & .001 \\
\hline PV & $3.74 \mathrm{E}-4$ & .000 & .305 & 2.775 & .006 & .000 & .001 \\
\hline RT & $-.004-$ & .008 & $-.025-$ & $-.516-$ & .606 & $-.020-$ & .011 \\
\hline
\end{tabular}

Table 9: the coefficients of reaction time

\begin{tabular}{|c|c|c|c|c|c|}
\hline \multirow[t]{2}{*}{ Model } & \multicolumn{2}{|c|}{$\begin{array}{l}\text { Unstandardized } \\
\text { Coefficients }\end{array}$} & $\begin{array}{l}\text { Standardized } \\
\text { Coefficients }\end{array}$ & \multirow[t]{2}{*}{$\mathrm{t}$} & \multirow[t]{2}{*}{ Sig. } \\
\hline & B & Std. Error & Beta & & \\
\hline AGE & .007 & .001 & .537 & 8.668 & .000 \\
\hline SPECTACLE & .070 & .012 & .069 & 5.894 & .000 \\
\hline TRADITION & .028 & .013 & .026 & 2.188 & .029 \\
\hline DHOURS & .005 & .002 & .058 & 2.533 & .012 \\
\hline $\mathrm{CH}$ & .003 & .001 & .229 & 4.255 & .000 \\
\hline $\mathrm{CV}$ & $-.006-$ & .001 & $-.328-$ & $-5.967-$ & .000 \\
\hline $\mathrm{PH}$ & .001 & .000 & .345 & 5.156 & .000 \\
\hline PV & .001 & .000 & .226 & 3.582 & .000 \\
\hline DEXPERIENCE & $-.004-$ & .001 & $-.150-$ & $-4.201-$ & .000 \\
\hline
\end{tabular}




\subsection{Error analysis}

By setting the dependent variable estimated on $\mathrm{x}$ axis and plotting the difference of observed and theoretical value with it on the other axis, the results are standardized residuals. Figure 9 and Figure 10 examine the linear model goodness of the accident rate and reaction time models and the distribution of points around the horizontal line drawn from $y=0$, the error can be observed from the scatter point distribution about the line and should be distributed in equal shape around the zero line, some error observed in top of $y=2$ of accidents rate standardized residuals and from top and bottom of the line out the $y=(-2,2)$ points on $\mathrm{y}$ axis of Reaction time standardized residuals as in Figure 9 and Figure 10 in sequence.

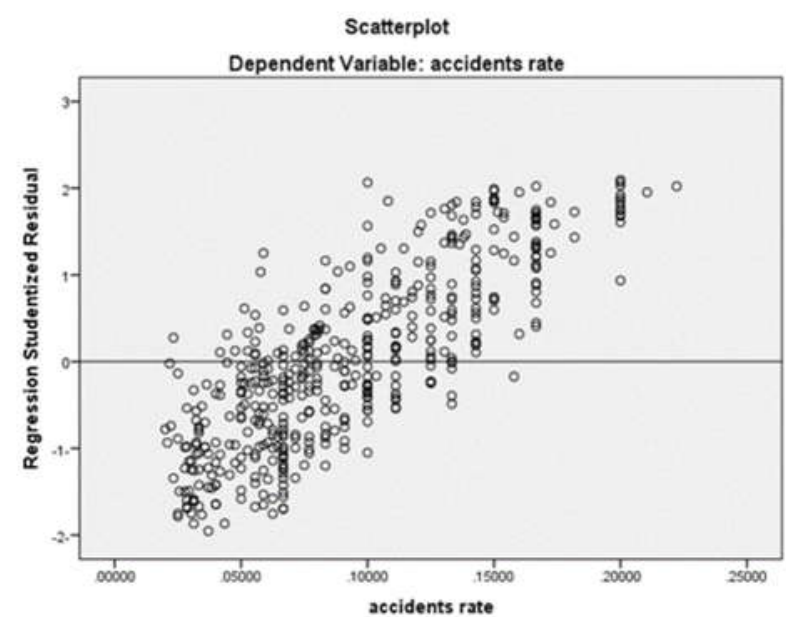

Figure 9: scatter plot of residuals and accidents rate.

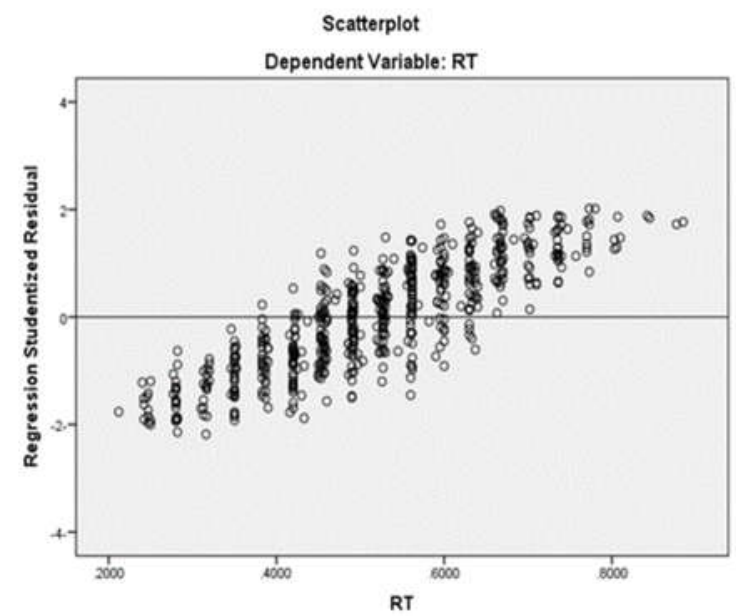

Figure 10: scatter plot of residuals and reaction time.

\subsection{Variance analyses of anova test}

To check the significant differences of the independent variables mean, the ANOVA applied by F-test. The F-test called the test of linearity which determines by a straight line the deviations of means. Table 10 and Table 11 shows the ANOVA test for RT and accidents rate in sequence. The results shows significant relation for the two models since the p-value is less than 0.05 .

Table 10: ANOVA test for reaction time

\begin{tabular}{|c|c|c|c|c|c|}
\hline & $\begin{array}{c}\text { Sum of } \\
\text { Squares }\end{array}$ & Df & $\begin{array}{c}\text { Mean } \\
\text { Square }\end{array}$ & F & Sig. \\
\hline 1 Regression & 153.318 & 7 & 21.903 & 1419.956 & .000 \\
Residual & 8.592 & 557 & 0.015 & & \\
Total & 161.909 & 564 & & & \\
\hline
\end{tabular}

Table 11: ANOVA test for accidents rate

\begin{tabular}{|cc|c|c|c|c|c|}
\hline & Model & $\begin{array}{c}\text { Sum of } \\
\text { Squares }\end{array}$ & df & $\begin{array}{c}\text { Mean } \\
\text { Square }\end{array}$ & F & Sig. \\
\hline 1 & Regression & 2.363 & 7 & .338 & 235.348 & .000 \\
& Residual & .284 & 198 & .001 & & \\
& Total & 2.647 & 205 & & & \\
\hline
\end{tabular}

\subsection{The results of analyses}

The following Table 12 summarizes the parameters extracted from the analyses and other calculations in equation forms. 
Table 12: results of predicted models

\begin{tabular}{|c|c|c|c|}
\hline Mathematical model & $\mathrm{R}^{2}$ & Adjusted $\mathrm{R}^{2}$ & $\begin{array}{c}\text { Std. error of } \\
\text { estimates }\end{array}$ \\
\hline $\begin{array}{c}\mathrm{RT}=(7 \text { Age- } \\
+ \text { 4DExperience }+ \text { 5Dhours }+\mathrm{PH}+\mathrm{PV}+3 \mathrm{CH}-6 \mathrm{CV} \\
+70 \text { Spectacle }+28 \text { Tradition }) / 1000\end{array}$ & 0.949 & 0.948 & 0.123 \\
\hline $\begin{array}{c}\text { rate }=\left(\text { AGE-3Dexperience-4RT }+ \text { Dhours }+\mathrm{PH}+3.74 * 10^{-7} \mathrm{PV}\right. \\
\left.+2.11 * 10^{-2} \mathrm{CV}\right) / 1000\end{array}$ & 0.89 & 0.886 & 0.039 \\
\hline
\end{tabular}

Where

$\mathrm{RT}=$ reaction time of drivers in Baghdad CBD (second)

Rate $=$ accidents rate (number of accidents +1 ) /experience of driver

Dhours $=$ average driving hours

Age $=$ age of driver (years)

DExperience $=$ experience of drivers (years)

$\mathrm{CH}=$ horizontal angle of clear vision (degrees)

$\mathrm{CV}=$ vertical angle of clear vision (degrees)

$\mathrm{PH}=$ horizontal angle of peripheral vision (degrees)

$\mathrm{PV}=$ vertical angle of peripheral vision (degrees)

Spectacle wearing and head cover wearing each denoted by 1 for presence and else is denoted by 0 In order to check the wellness of the model with data, $\mathrm{R}$ value calculated should not be exceeded by the critical $R$ value (tabulated $R$ value). The tabulated $R$ value for each model predicted is less than the calculated $\mathrm{R}$ value, so the relation between independent variables and the predicted variable is strong, as in Table 13. $\mathrm{DF}=\mathrm{n}-2$, significance level $=0.05$

Table 13: tabulated R-values for the final model

\begin{tabular}{|c|c|c|c|}
\hline dependents & $\mathrm{N}$ & R-calculated & R-tabulated \\
\hline RT & 804 & 0.976 & 0.0723 \\
\hline Accidents rate & 675 & 0.949 & 0.0789 \\
\hline
\end{tabular}

\subsection{Models limitations}

The data used limited to rage of maximum and minimum values; the purpose of limitation is not meaning that the work is not effective; simply it is only a caution of data limits used as in Table 14.

Table 14: Summaries of models limitations

\begin{tabular}{|c|c|c|c|}
\hline Model & minimum & maximum & Mean \\
\hline Reaction time & 0.212 & 0.887 & 0.522 \\
\hline Accidents rate & 0.02 & 0.22 & 0.0985 \\
\hline
\end{tabular}

\subsection{Validity of the predicted models}

To assess the performance of predicted models by regression analyses, a good techniques used for that purpose, by plotting observed and estimated data. If the data plot tend to be in angle of 450 , then we have best results, otherwise, less performance is performed. This method uses about $30 \%$ of the data for the validation, and $70 \%$ for the predicted equations. Figure 11 and Figure 12 shows the validation of accidents rate and reaction time models. The Figure 13 and Figure 14 shows the shape of the normal probability plot of histogram for the Two models RT and accidents rate in sequence, the results of the two models $\mathrm{p}<0.05$ then the distribution is not normal. Figure 15 and Figure 16 shows the graph of predicted and measured data, for accidents rate and reaction time dependent variables, the predicted data tend to be less than measured data in RT values most of times and an error noticed in both predicted values because of the deviation from the straight line in 45 degree. The accidents rate values are better than RT in the distribution of scatter around the reference line (45o) from the origin

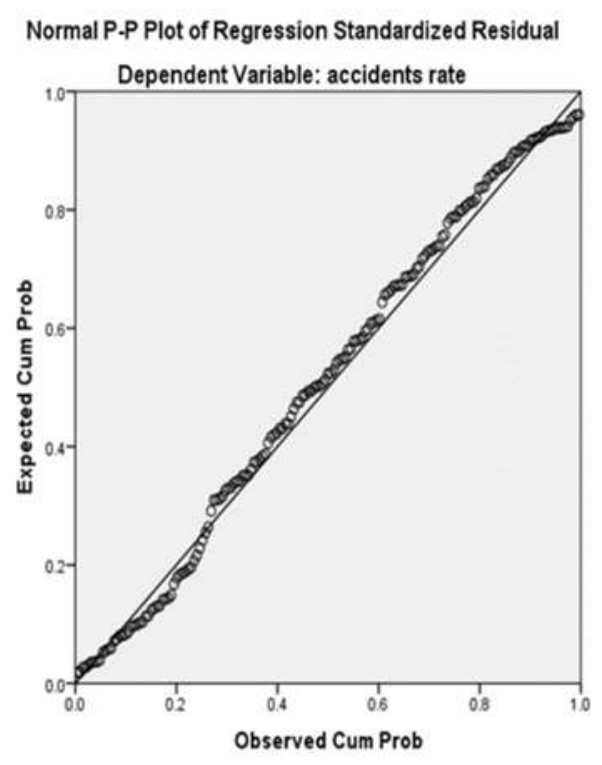

Figure 11: the estimated value of accidents rate 
Normal P-P Plot of Regression Standardized Residual

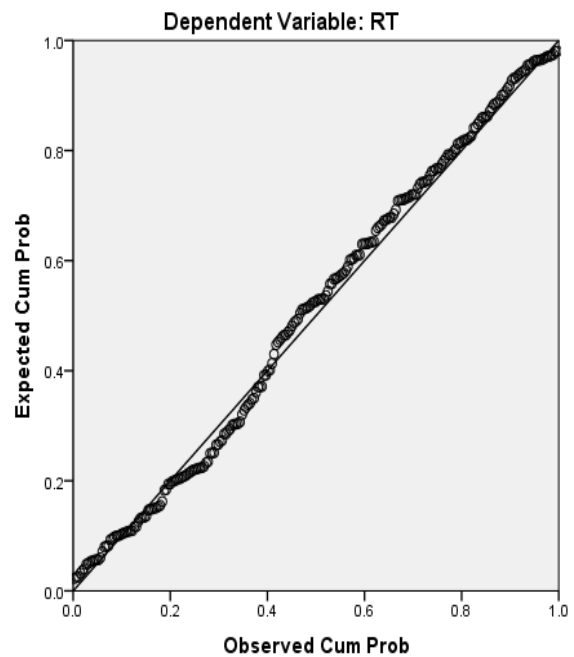

Figure 12: the estimated value of drivers' reaction time

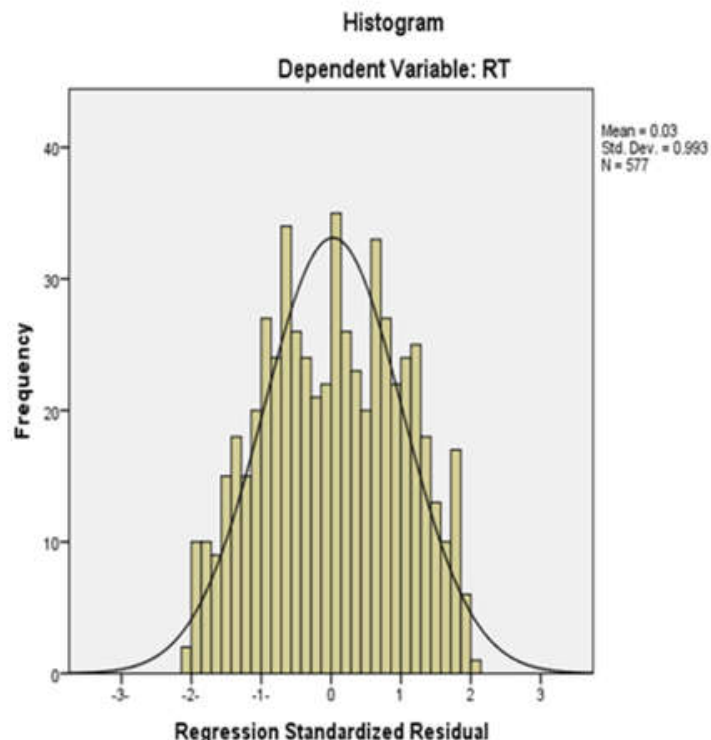

Figure 13: normal probability plot with histogram for reaction time model

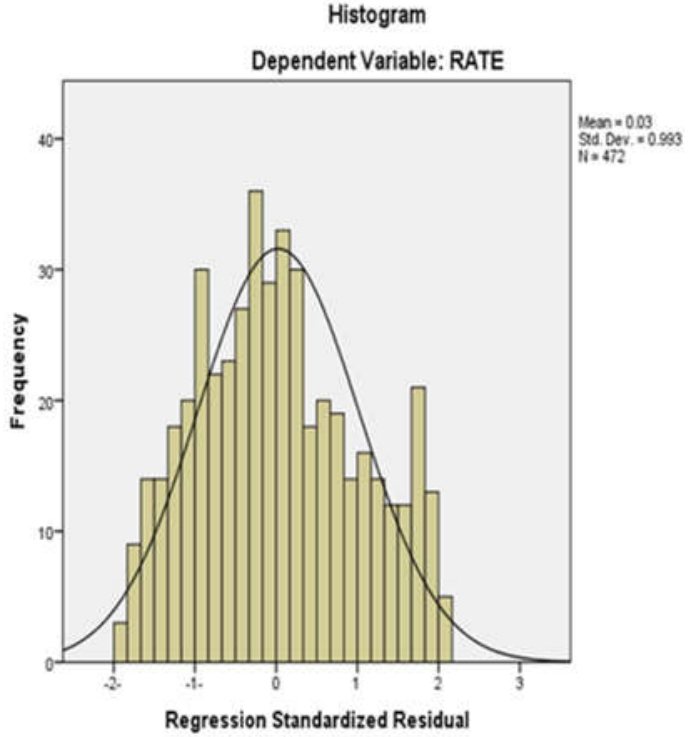

Figure 14: normal probability plot with histogram for accidents rate model

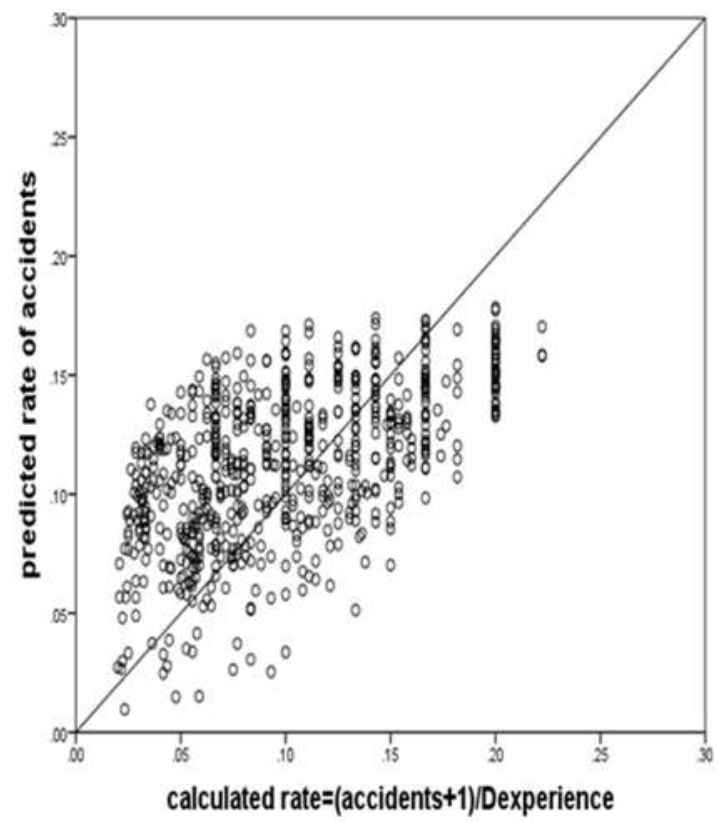

Figure 15: shows the predicted vs. calculated accidents rate data 


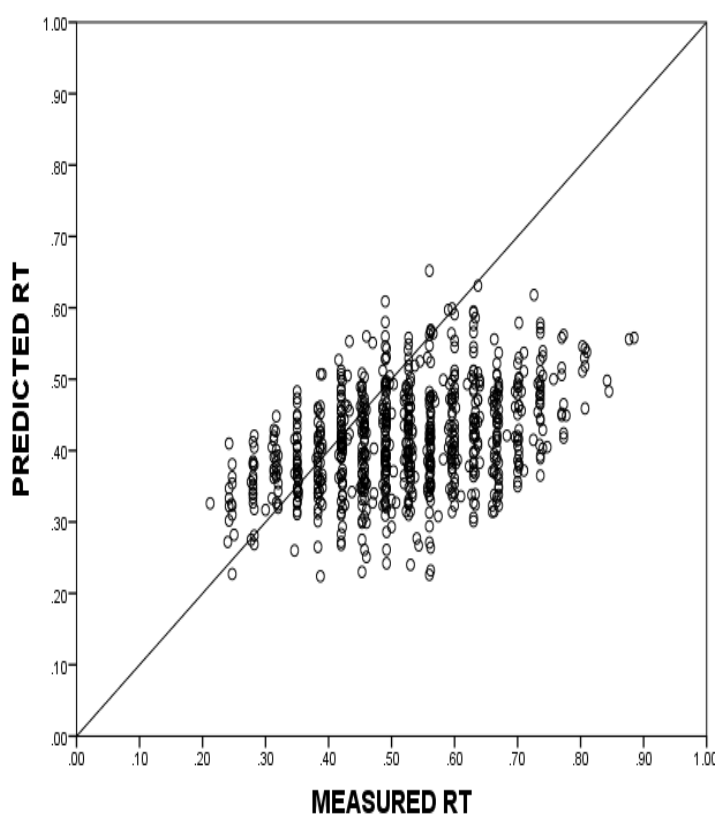

Figure 16: shows the predicted vs. measured reaction time data

\section{Conclusions}

1. Minimum reaction time value for age group (29$39)=0.5708(\mathrm{sec})$, while the maximum reaction time value for age group $(>=51)=0.6974(\mathrm{sec})$ in an increase about $22 \%$

2. 2.The accidents participation for age group $>50$ years recorded minimum accident participation of about $18.8 \%$, and the age group 29-39 years recorded maximum accidents participation of $34 \%$ of total accidents participations.

3. Tradition wearing and spectacle together affects negatively the RT of driver more than other cases to about $15.5 \%$ increase, while spectacle and tradition wearing individually increases the RT to $8.33 \%$ and $8.84 \%$ in sequence

4. 4.The accidents rate (accidents +1 /driving experience) decreases with the increase in age group from maximum accidents rate of 0.482 for age group (18-28) to a minimum accidents rate of
0.0808 for age group $>=51$ years, the decrease is $83 \%$.

5. 5.The visual acuity $(\mathrm{CH} \& \mathrm{CV})$, Reaction time and driving hours did not show significant effects on accidents rate (sig. $>0.05$ ), while it did on reaction time of drivers.

\section{References}

[1] Al-Madani, H. and Al-Janahi, A.R., 2002. Assessment of drivers' comprehension of traffic signs based on their traffic, personal and social characteristics. Transportation research part F: Traffic psychology and behavior, 5(1), pp.63-76.

[2] Garber, N.J. and Hoel, L.A., 2009. Traffic and highway engineering. Cengage Learning.

[3] Gregersen, N.P., Berg, H.Y., Engström, I., Nolén, S., Nyberg, A. and Rimmö, P.A., 2000. Sixteen years age limit for learner drivers in Sweden —an evaluation of safety effects. Accident Analysis \& Prevention, 32(1), pp.25-35.

[4] McCuen, R.H., 1985. Statistical methods for engineers. Prentice Hall.

[5] Neville, A.M. and Kennedy, J.B., 1964. Basic statistical methods for engineers and scientists. In Basic statistical methods for engineers and scientists. International Textbook.

[6] Sarsam S.,2006, Evaluation of driver's characteristics in Mosul, University of Sharjah, J Pure Appl Sci.; 3(1): 33-48p

[7] Sarsam, S., 2012, Assessing Driver Characteristics at Baghdad CBD. In Proceedings, 6th Jordanian Conference of traffic safety (pp. 18-20).

[8] Sarsam, S., 2015, Comparative Assessment of Drivers Characteristics at Baghdad Urban and Suburban Area', IJTETS International Journal of Transportation Engineering and Traffic System, 1, pp. 45-55. Available at: www.journalspub.com

[9] www.fliniski.com. 


\section{Appendices}

Table .15: some of drivers data tested in fields

\begin{tabular}{|c|c|c|c|c|}
\hline 744 & 511 & 783 & 694 & Drivers no. \\
\hline 60 & 53 & 63 & 52 & Age \\
\hline Primary & Primary & Primary & Secondary & Educational level \\
\hline Yes & Yes & Yes & Yes & License presence \\
\hline Unsatisfactory & Unsatisfactory & Unsatisfactory & Fair & Traffic education \\
\hline 3 & 2 & 6 & 0 & Number of Accidents \\
\hline 2 & 1 & 2 & 0 & Responsible \\
\hline 1 & 1 & 4 & 0 & Not responsible \\
\hline 0.582 & 0.527 & 0.63 & 0.56 & $\mathrm{RT}$ in sites(sec) \\
\hline $\mathrm{PC}$ & $\mathrm{PC}$ & Mini bus & $\mathrm{PC}$ & Vehicles type \\
\hline Rural & Rural & Urban & Urban & Area type \\
\hline No & No & Yes & Yes(1) & Spectacle wearing \\
\hline Yes & Yes & Yes & $\mathrm{No}(0)$ & Head cover wearing \\
\hline 37 & 38 & 40 & 31 & Driving experience \\
\hline 9 & 6 & 10 & 12 & Driving hours/day \\
\hline 14 & 19 & 25 & 38 & $\mathbf{C H}$ \\
\hline 12 & 18 & 23 & 36 & $\mathrm{CV}$ \\
\hline 104 & 128 & 115 & 120 & PH \\
\hline 80 & 76 & 57 & 85 & PV \\
\hline 140 & 247 & 1012 & 439 & Drivers no. \\
\hline 57 & 52 & 34 & 46 & Age \\
\hline Read \& write & Illiterate & Read \& write & University & Educational level \\
\hline Yes & Yes & Yes & Yes & License presence \\
\hline Good & Fair & Unsatisfactory & Fair & Traffic education \\
\hline 0 & 1 & 1 & 6 & Number of Accidents \\
\hline 0 & 0 & 1 & 0 & Responsible \\
\hline 0 & 1 & 0 & 6 & Not responsible \\
\hline 0.56 & 0.523 & 0.49 & 0.52 & $\mathrm{RT}$ in sites(sec) \\
\hline Minibus & $\mathrm{PC}$ & $\mathrm{PC}$ & Minibus & Vehicles type \\
\hline Rural & Rural & Urban & Rural & Area type \\
\hline No & No & No & $\mathrm{No}(0)$ & Spectacle wearing \\
\hline No & Yes & Yes & Yes(1) & Head cover wearing \\
\hline 40 & 38 & 18 & 28 & Driving experience \\
\hline 2 & 7 & 7 & 8 & Driving hours/day \\
\hline 60 & 47 & 27 & 22 & CH \\
\hline 45 & 32 & 25 & 19 & $\mathbf{C V}$ \\
\hline 140 & 115 & 143 & 122 & $\mathbf{P H}$ \\
\hline 117 & 71 & 82 & 83 & PV \\
\hline
\end{tabular}




\section{تقييم خصائص السواق في المناطق التجارية لبغداد حبإر محد علـي سلمان 1،*، أستاذ سعد عيسى سرسم 2} قسم الهندسة العدنية، جامعة بغداد، بغداد، العراق،

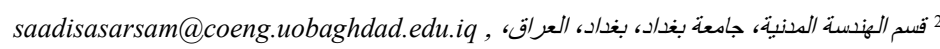
"الباحث المثثل: حيدر محد علي سلمان، البريد الاكتروني: hyder_alkhafaji@yahoo.com 2019 شر في: 31 حزيران

الخلاصة ــ العدد الضخم من الحو ادث جعلت در اسة مسببات الحوادث من الاولويات لتصميم الطرقب مو اقع العلامات المرورية وتحديد اعمار السائقين

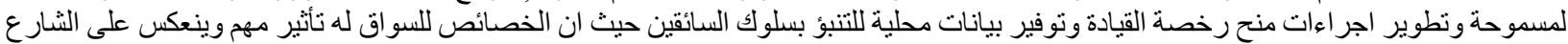

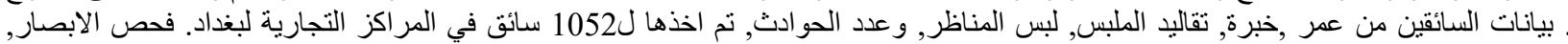

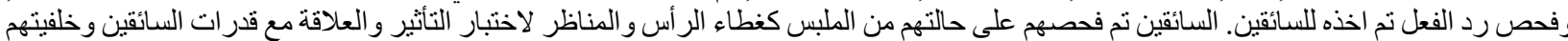

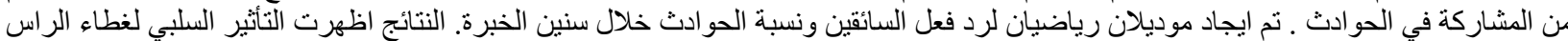

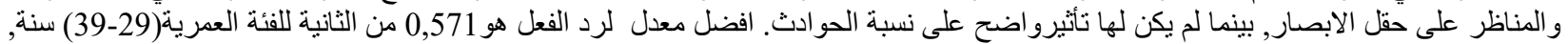

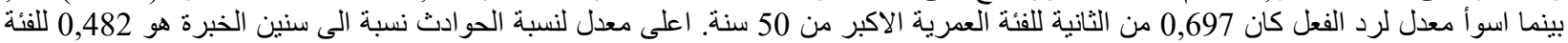

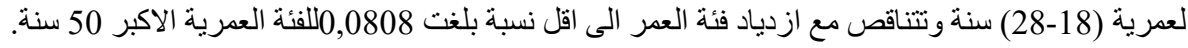
الكلمات الرئيسية ـ رد الفعل,نسبة الحو ادث,خصائص السو اق,غطاء الر أس,نظار ات, موديل رياضي. 